The Monist 75(no. 2, 1992): 250-278.

\title{
DISVALUES IN NATURE
}

\section{Disvalues and values}

To accentuate the positive one can eliminate the negative. A touchstone for any theory of truth is its theory of error; a theory of value needs to handle disvalue. Philosophers, lately exercised about values in nature, have not yet much asked about disvalues there. They have also cautioned against committing an alleged naturalistic fallacy. The usual version, the positive naturalistic fallacy, argues from is to ought. Nature is described such and such a way; that is a good thing and ought to be so. But, we are warned, "natural" does not imply "right." The unusual version, the negative naturalistic fallacy, argues to ought not. Nature is such and such a way; this ought not to be so.

This locates disvalue in nature, but on what grounds? Possibly there is a suppressed, implicit premise: I (or other humans) choose for good reasons supporting human welfare to disvalue this matter of natural fact. Now the conclusion does follow, given my premises. But these are only "my" premises. Take away my preferences and reasons, and there is no disvalue in nature. Opportunistic humans operate as a preference sieve through a booming, buzzing confusion, a kaleidoscopic churn where no event is of value or disvalue of itself. But assume our human outlook, and we cannot avoid valuing some and disvaluing other events in nature.

Often there is a stronger claim. A certain natural condition is bad, whether or not any humans are around. When I come on scene, I can evaluate it so. I may also suffer from this preexisting disvalue; I ought to remedy it if I can. So "my" premises are describing the natural case; my subjective preferences are registering an objective disvalue. In this latter case, no fallacy is committed; to the contrary truth is discovered, only, alas, unhappy truth.

Charles Darwin exclaimed that the process is "clumsy, wasteful, blundering, low, and horribly cruel." ${ }^{1}$ John Stuart Mill cursed nature as an "odious scene of violence." ${ }^{2}$ Thomas Huxley admonished, "Let us understand, once for all, that the ethical process of society depends, not on imitating the cosmic process, still less on running away from it, but in combating it." ${ }^{3}$ George Williams insists, "The process and products of evolution are morally unacceptable and act in opposition to the ethical progress

Copyright (C The Monist: An International Quarterly Journal of General Philosophical Inquiry, Open Court Publishing Company, Chicago, Illinois. Reprinted by permission. 
of humanity. . . What is, in the biological world, normally ought not." ${ }^{4}$ These seem to be judgments disvaluing objective natural history. If true, there could prove little cause for biological conservation out of respect for nature.

Disvalue might be discovered in natural products oblivious to the systemic processes. If the disvalue comes only by human preferences, origins are irrelevant. But nature is processes as much as products. Possibly, a disvaluable or valueless process has occasionally produced valuable products, though it would be anomalous if there were a longstanding, high statistical correlation between such a disvaluable process and its valuable products. When valuing nature it is difficult to separate the evolutionary past from the ecological present, and we need to connect both with the ethical future.

An intermediate position is that evolution leads sometimes to good, sometimes to bad things, and that on balance this is a zero sum game. The goods and bads cancel each other out, like heads and tails when tossing a coin. Or the dice might be loaded, either toward values or disvalues.

Another position, only seemingly intermediate, holds that the evolutionary processes and products are devoid of value. This does not mean that each result lies still within the category of valuation, their average hitting the scale at zero. Rather, evolution is entirely off the value scale. Hamlet mused, "There is nothing either good or bad, but thinking makes it so." More accurately, preferring makes it so. Disvalue is as added as value; the naked term is non-value, but even that term backs into nature pejoratively, because it defines a thing by finding entities absent value. Natural things - if we can find ourselves up to this thought experiment - just are, neither present nor absent value; rather they lie outside the domain of value (and therefore outside nonvalue and disvalue categories), until humans or other conscious valuers arrive and ignite values or disvalues.

We can say that natural processes and products always have the standing possibility of valuation (or disvaluation), but that is to categorize them in terms of possibilities when humans come on scene. Whether such a standing possibility can be retroactively posited as some real potential there absent humans is doubtful. True enough, we cannot formulate the question whether there is value in nature independently of human experience; but can we formulate a question that reaches outside of human experience? Notice that both those who do and those who do not find or assign value, disvalue, or nonvalue, think they can describe what is really there or not there, outside of the perceptions in the eye of the human beholder. Even the nullvalue view thinks to know what categories are absent in nature. 
Sometimes, we view from our human niche, when we value timber and disvalue wildfire that destroys it. But sometimes we wish a view from no niche, that of an ideal Earth-observer. This need not be absolute, but it will be regional or global. This view is made with our human perceptual and cognitive equipment, but we can partially at least distinguish what we see from how we are able to see it.

Notice carefully that the appropriate evaluative category is not nature's moral goodness, for there are no moral agents in nonhuman nature. The appropriate category is one or more kinds of nonmoral goodness, better called nature's value. Such value is not to be mapped by projection from culture, much less from human moral systems within culture. It may be that we humans, who are moral agents, ought or ought not to imitate this process; such decision and action will be a moral matter. But the evaluation of nature is not yet moral. Nature is a-moral but that does not imply either avalue or neg-value. That may be where the suspected fallacy lies.

One appropriate category on Earth will be its biological goodness, the extent to which the natural system is pro-life, prolific. We must evaluate phenomena such as: the achievement of diversity and complexity out of simplicity, the mixture of order and contingency, the nomothetic and the idiographic, autonomy and interdependence, individualism and community, endurance through struggle. None of these results can be called moral. Rather, these are creative activities. They may have resultant worth.

If we ask whether all natural things are made for human benefit (either by divine design or natural selection), then it is clear that the answer is that they are not. From this perspective, many things in nature will have no value or disvalue. For Homo sapiens some things will prove of value, likeliest some found in our evolved niche, if we have one. Or if we have rebuilt our niche culturally, valuable things will be those that we use as natural resources, remaking them into instruments of culture. But if we ask whether natural things are well made in and by themselves, an answer still needs to be sought.

Philosophers have been chary and fastidious about granting objective value in nature, but they have often been quite willing to allege objective disvalue in nature. But by parity of reasoning, those willing to grant objective disvalue must also consider objective value. Indeed, we shall argue that such disvalues point to values more evidently there. The view of nature that results is not value negative, much less value neutral; it embeds values in biotic community. The argument must follow opposites in conflict and resolution, and this will require a series of gestalt switches, finding out what is actually going on in nature, evaluating it prima facie and revaluating it at more depth. 
Also, take caution against forgetting the pluralism in nature. There are myriad sorts of things and they are differently made.

\section{Predation}

There is quite a list of candidate disvalues. One is predation. Indisputably, for a prey animal, it is bad to be eaten; death results. If a tiger eats a human, we are horrified. And if a tiger eats a monkey? The monkey screams, and "nature, red in tooth and claw" has seemed quite tragic. Richard Dawkins concludes that Tennyson's famous phrase "sums up our modern understanding of natural selection admirably." All organisms are "like successful Chicago gangsters." ${ }^{7}$ Steve Sapontzis finds predation lamentable: "Where we can prevent predation without occasioning as much or more suffering than we would prevent, we are obligated to do so." 8 These judgments, made from a human perspective, are judgments from the perspective of any prey and judgments about processes deeply embedded in ecosvstems.

The disvalue to the prey is, however, a value to the predator, and, with a systemic turn, perspectives change. The violent death of the hunted means life to the hunter. There is not value loss so much as value capture; nutrient materials and energy flow from one life stream to another, with selective pressures to be efficient about the transfer. The pains of the prey are matched by the pleasures of the predator. Should we register the amounts of each to compute the net? Or is the hedonistic criterion perhaps not the most relevant one? We need to ask what biological achievements result from predation?

The wolf is not a big, bad wolf; it is one of the most handsome animals on Earth. Many wish to reintroduce wolves to Yellowstone. In Africa, tourists most want to see the big cats. Florida school children chose the lithe, supple panther as their state animal. We admire the muscle and power, the sentience and skills that could only have evolved in predation. Such aesthetic experience is in the eye of the human beholder, but the biological achievements are objective in cat and wolf. Are these good products of a bad process? Or does something about the creative process require predation?

Autotrophs synthesize their own food; heterotrophs eat something else. Could we have had a world with only flora, no fauna? Possibly not, since in a world in which things are assembled something has to disassemble them for recycling. In any case, no one thinks that a mere floral world would be of more value than a world with fauna also. In a floral world, there would be no one to think. Heterotrophs must be built on autotrophs, and no autotrophs are sentient or cerebral. 
Could there have been only plant-eating fauna, only grazers, no predators? Possibly, though probably there never was such a world, since predation preceded photosynthesis. Even grazers are predators of a kind, though what they eat does not suffer. Again, an Earth with only herbivores and no omnivores or carnivores would be impoverished. The animal skills demanded would be only a fraction of those that have resulted in actual zoology-no horns, no fleet-footed predators or prey, no fine-tuned eyesight and hearing, no quick neural capacity, no advanced brains.

Nor are all benefits to the predators. The individual prey, eaten, loses all; but the species may gain as the population is regulated, as selection for better skills at avoiding predation takes place, and the prey not less than the predator will gain in sentience, mobility, cognitive and perceptual powers. Being eaten is not always a bad thing, even from the perspective of the prey species. The predator depends on a continuing prey population; they have entwined destinies.

A rattlesnake has fangs - weapons - and people and animals can get hurt by them. That is clearly a disvalue, if bitten. But fangs are of value to the snake, and their disvalue is close-coupled with value. Indeed, in the systemic picture, fangs are teeth, teeth belong in the food chains by which animals eat. Sometimes animals use the same tools that secure food also as weapons to protect themselves against being eaten. There is nothing inherently disvaluable about teeth, including incisors or canines. A human eating an apple is no more, no less ungodly than a snake eating a mouse. A photosynthetic world would be a largely immobile world. Some species must sit around and soak up sunlight; other species will capture this value to fuel mobility. Still other species will rise higher on the trophic pyramid, funded by capturing resources from below for greater achievements in sentience, cognition, and mobility.

We humans stand in this tradition, omnivores over most of our timespan. Our ancestors were hunters until the advent of domestication and agriculture a few thousand years ago; even in domestication meat eating continues. Perhaps we ought to kill food animals humanely, perhaps we even ought now to stop eating them. But meanwhile we face the paradox that without predation in our past we should not be here to deliberate the question at all.

A world without blood would be poorer, but a world without bloodshed would be poorer too. Among other things, it would be a world without humans - not that humans now cannot be vegetarians but that the evolution of humans would never have taken place. We are beginning to see that disvalues are often subtly transmuted into values, especially if we transpose 
the question from one of human preferences into one about systemic processes.

\section{Parasitism}

Alexander Skutch concludes, "After long pondering, I believe that I can define good and evil in terms to which even a biologist . . . can hardly take exception. . . . The great evil of life is parasitism." ${ }^{9}$ Parasitism is predation minus what we just admired. The lofty power, sentience, cognition, and locomotion are gone; the degenerate parasite just sucks nutrients out of the host and cripples it. Parasites do not even contribute the photosynthetic energy collection supplied in plants. Parasites often lose skills they formerly had-eyes, wings, even their brains. As humans we dislike parasites, but the judgment here is not mere human preference. It is based on objective facts recognizing a bad feature in a generally positive evolutionary system. "Parasitism has taken its tremendous toll of life with scarcely any return that we can see; it has led to retrogression rather than to progress. Hence we may call it the greatest evil of life." ${ }^{10}$

Ichneumon wasps in larval stages are parasites that slowly excavate caterpillars from within. Stephen Jay Gould reels from the grisly business, "I suspect that nothing evokes greater disgust in most of us than slow destruction of a host by an internal parasite - gradual ingestion, bit by bit, from the inside." ${ }^{11}$ Gould concludes, rightly, that nature is nonmoral; the wasps cannot be faulted, nor can we morally censure the system they inhabit. But have we a disvalue? Gould finds himself bewildered and is unsure whether he can ask, much less answer, the question. E. O. Wilson remarks that much parasitism is an "evolutionary sink" the end of which is "a state of abject dependence on the host species." 12 Notice, though, that seldom does the system as a whole degenerate. The parasite that loses skills borrows skills that remain in the host.

But contemporary parasitology questions the extent to which parasites are either degenerate or detrimental to their hosts. Their evolution is often doubtfully to be termed "regressive"; the exchange of free-living skills achieves less evident but biochemically sophisticated skills. Arthur W. Jones concludes, "Parasite life cycles are extremely ingenious.... Parasites may be, not less, but more evolutionarily progressive than their hosts." ${ }^{13}$ Much of this is microscopic; most of it is invisible to the uneducated observer.

Most parasites do not harm their hosts and many are beneficial. We could almost have predicted this, had we listened to evolutionary theory, 
since the success of a parasite is closely tied to that of its host species. There is much evidence (and some counterevidence) that in the most advanced parasite-host coevolution the parasites show minimal pathogenesis. A. C. Allison concludes, "Long co-evolution of vertebrate hosts and parasites results in infections of low virulence." ${ }^{14}$ The ill-adapted parasite species slays its host species and goes extinct; better-adapted parasites co-exist with their hosts, and the best-adapted will benefit their hosts at the species and even at the individual level. Overvirulence to the host decreases the parasite's chances of survival; a parasite can increase its chances by benefiting its host organism. Parasites also regulate animal populations.

There is obvious disvalue in much parasitism; this may be, on average, a glitch in the system. But it is almost as clear that virulence is not intrinsic to parasitism and that the systemic selective pressures are often positive even when the trend is sometimes locally negative. "Parasitism, one of life's great phenomena, possesses a quality of goodness that has largely been overlooked." ${ }^{15}$

Parasitism is a subroutine in a larger value-capture system. It cannot be a bad thing for an organism to depend on another for skills or metabolisms it lacks, else humans (who cannot photosynthesize) eating plants (which can) would be a parasitic evil. All heterotrophs of spectacular evolutionary achievement live in "abject dependence" on plants. Meanwhile, it might be a bad thing if some life forms took degenerating routes. No one wants to say that there are no disvalues in nature; but we do want to keep them in perspective in the fuller picture. The whole idea of parasitism is conceptually parasitic on values elsewhere present and flourishing enough to be parasitized. The disvalue, parasitism, is privative on some value, autonomous life, but all life is interdependent. There could be no world composed entirely of parasites, taking in each other's values, so to speak. However much disvalue parasitism introduces, there must be positive value in excess of it, else the parasite could not parasitize.

\section{Selfishness}

Selfishness is rightfully lamented in humans but immoral selfishness can be a disvalue in nature only if there is moral agency present. Who or what are such moral agents? Monkeys? Snakes? Trees? Mountains? Light-

ning bolts? Evolution? Genes? Systemic nature? Every organism is full of "selfish genes," Richard Dawkins tells us, the only kind of genes there are. Why does George Williams disvalue evolutionary nature so? Because it "can honestly be described as a process for maximizing short-sighted selfishness." ${ }^{16}$ But if there is no moral agency present, if genes cannot be 
selfish in any sense that we disvalue in human ethics, that is not an "honest" (= accurate) description after all. Moreover, evolution has no "sight" and cannot be faulted for being short-sighted. What seems to be claimed is that there are processes in evolution that moral agents, when they appear, will disvalue - rectify or repudiate - in their own cultural life. The alleged selfishness is said to be located in one organism's looking out after its own interests or in assisting relatives and offspring, when it shares genes.

Though there is no moral selfishness in nature, there are selves - biological organismic identities to be preserved (not to be confused with psychological egos). Such a self-impulse cannot in itself be a disvalue. Quite to the contrary, this self-impulse just is the life impulse, the principal carrier of biological value. An organismic self is not a bad thing, nor is the defense of it.

Can we describe the natural system more accurately and less pejoratively? The system evolves organisms that attend to their immediate somatic needs (food, shelter, metabolism) and that reproduce themselves in the very next generation. In the birth-death-birth-death system a series of replacements is required. The organism must do this, it has no options; it is "proper" for the organism to do this (Latin proprium, one's own proper characteristic). Somatic defense and genetic transmission are the only conservation activities possible to most organisms; they are necessary for all, and they must be efficient about it.

If there is some disvalue, this must lie in an overextension or aberration of the self-impulse. When a subordinate monkey relinquishes a feeding site to a dominant, the dominant may be said to have "selfishly" taken over. Or males may "selfishly" dominate females or defend territories. Such behavior, says Williams, is "not only selfish in some theoretical sense but patently pernicious. Only the morally and intellectually dishonest could label it otherwise. ${ }^{17}$ But if we strike out the negative moral overtones and replace this with positive self-preservation, what is going on? The monkey with the superior genes gets fed and bred; the monkey with the inferior genes does not, or at least not first. What is so disvaluable about that? Should it rather be the other way round-that the inferior genes get nourished and propagated, the superior ones not so?

If we cast the event in terms of values defended, what is of value here (the superior genome) gets transmitted, maintained through feeding and breeding, while what is of relative disvalue gets selected against. There is no moral agency at issue; what is at stake is value that is self-actualized. To ask these monkeys to behave as altruistic humans misunderstands the events and misvalues them accordingly. Read out the immorality, and the picture looks different. Take off the dark glasses and put on clearer ones. It is a 
category mistake to describe (and censure) what goes on in wild nature with terms borrowed from culture and projected onto nature. There is nothing here particularly disvaluable, which moral agents, when they come, will want to deplore and rectify. The alleged selfishness is really the conservation of value intrinsic to the organism in the only manner possible and appropriate to it.

All such contests at feeding and reproduction are endured for "selfish" advantage by males or females only in a problematic sense, since the somatic individual soon dies anyway. A better way of interpreting events is that the contest is to share genes. It is self-defense in one sense, but if males and females spend time, energy, and effort to reproduce, this is selfsacrificing in another sense. By those who resolve to see everything through selfish lenses, this will (rather confusingly) be called selfishness again, seen from the nonmoral genetic level. But we get a much clearer picture of what is going on if we interpret this as values being transmitted over generations.

Although the organism is engaged in a short-range reproduction of its kind, the systemic processes are neither short-range nor do they selfishly maximize only one kind. The system is 3.5 billion years old; it has steadily produced new arrivals, replacements, and elaborations of kinds, going from zero to five (or ten) million species, through five (or ten) billion turnover species in a kaleidoscopic panorama. Any particular organism, in the subroutines of this system, actualizes its own values and transmits these to the next generation (with variations). That is all any one organism has the capacity to do, a capacity of critical value. The result is a quite dramatic story, not just a long, long chain of "patently pernicious" short-sighted selfishness. The value account seems quite descriptively plausible, not at all "morally and intellectually dishonest."

Of course, when humans pass over into culture, they may wish to transcend or revise the now-relaxed processes of natural selection. A good thing in nature may not be a good thing in culture, and vice versa. We certainly do not want to turn to amoral nature for templates with which to judge moral events in culture. That too is a category mistake. Interhuman ethics is nowhere to be educated by watching monkeys, or wildflowers, or bolts of lightning.

\section{Randomness}

"Nature does nothing in vain. Natura nihil agit frustra"18 But, contrary to Sir Thomas Browne's famous claim, some biologists find that nature does nothing with any bent toward value. Physical and chemical laws 
operate there, as do some biological regularities, such as survival of the fittest, but the system is mostly just contingent. Unrelated and probabilisticallyrelated causal lines impinge, resulting in lucky and unlucky events. When an elk, crashing through the forest, accidentally steps on the nest of a thrush, crushing the young, an event of disvalue has occurred, without redeeming construction of value. The elk gains nothing by the accident; had it stepped elsewhere nothing would have been really different for it. The thrush has only lost. Windblown seeds fall, some on rock or unsuitable ground. Some get eaten. Some sprout to get killed by a frost; some die when the rains fail.

Some judge this to be local disvalue in a null-valued system. A random event generator lies outside the domain of value generation, even though its output is accidentally valuable or disvaluable on rare occasions. But when we place local bad luck into the larger system, is this systemically a disvalue? The organism by its genetic programming, instincts, perceptions, and conditioned learning modifies its exposure to luck and acts as a preference sieve, sometimes but not always accumulating the lucky upstrokes and discarding the unlucky downstrokes. Should we value the capacity to catch or discard, while cursing the world of contingency?

But that is to value the retention side as though the supply side were not logically and empirically necessary. It does not seem possible for the world to be otherwise if there is to be autonomy, freedom, adventure, success, achievement, emergents, openness, surprise, and idiographic particularity. The feet of free-ranging elk cannot be bound. We inhabit a world where luck is one of the required ingredients in the arrival, construction, and conservation of value. There is a combination of deterministic and opportunistic processes, a mixture of vitality with necessity and possibility. We are not dealing with probabilities and random walks so much as with developing story lines.

Frances Crick complains that biology has no "elegance." Organisms evolve happenstance structures and wayward functions that have no more overarching logic than the layout of the Manhattan subway system. ${ }^{19}$ Stephen Jay Gould insists that the panda's thumb is evolutionary tinkering and that orchids are "jury-rigged."20 Evolution works with what is at hand, and makes something new out of it.

But what is so disvaluable about that? The achievements of evolution do not have to be optimal to be valuable; and if a reason that they are not optimal is that they had to be reached historically along story lines, it is more valuable to have history plus value as storied achievement than to have "elegant" optimal value solutions without history, autonomy, or 
adventure. Organismic vitality is better than regimented simplicity. The elegance of the thirty-two crystal classes is not to be confused with the grace of life lived in the midst of perpetual perishing.

How global is this contingency? Viewing natural selection systemically, some hardnosed scientists are reluctant to see any value increase, because their theory, as usually interpreted, does not entitle them to see any. Despite the use of "better" with "adaptation," the theory predicts only survivors and leaves entirely open whether the survivors have progressively more worth. If the environment that species track is drifting, then they do not progress toward anything, they just track drift—buffeted about by aimless geomorphic processes. The only outcome that natural selection can promote is capacity to survive, an independent variable with regard to increasing complexity or diversity. Like a rotating kaleidoscope, there is change without development.

The biological panorama, more or less packed since Cambrian times, is a scene of steady turnover, but later-coming grasses or crustaceans are not any better than earlier, extinct ones; they are just different. Indeed, in climates growing colder or drier fewer species may live there later than did before. There are fewer dinosaurs now than in Cretaceous times, fewer birds than in Pleistocene times. Gould insists, "We are the accidental result of an unplanned process ... the fragile result of an enormous concatenation of improbabilities, not the predictable product of any definite process." ${ }^{21}$ There may result "chance riches," 22 but the system is without value heading. Note that this claim is intended to describe objective natural history. Both descriptively and axiologically, there is only luck.

But something is increasingly learned across evolutionary history: how to make more kinds and more complex kinds. This may be a truth about natural history, even if neo-Darwinism is incompetent to say much about how this happens. Cold and warm fronts come and go, so do ice ages. There are rock cycles, orogenic uplift, erosion, and uplift again. But there is no natural selection there, nothing is competing, nothing is surviving, nothing has adapted fit, and biology seems different. All those climatological and geomorphological agitations continue in the Pleistocene period more or less like they did in the Precambrian, but the life story is not the same all over again. Where once there were no species, now there are five to ten million. It seems evident that, on average and environmental conditions permitting, the numbers of life forms start low and end high.

J. W. Valentine concludes for marine environments: "A major Phanerozoic trend among the invertebrate biota of the world's shelf and epicontinental seas has been towards more and more numerous units at all 
levels of the ecological hierarchy. ... the biosphere has become a splitter's paradise" 23 There is "a gradually rising average complexity." 24 The story of terrestrial life is even more impressive, because the land environment is more challenging. Reptiles can cope in a broader spectrum of humidity conditions than amphibians. Mammals can cope in a broader spectrum of temperature conditions than reptiles. Genetic and enzymatic control is surpassed by neural networks and brains; there are increases in sentient capacity, locomotion, acquired learning, communication, language acquisition, and in manipulation.

Francisco J. Ayala concludes, "Progress has occurred in nontrivial senses in the living world because of the creative character of the process of natural selection." 25 Theodosious Dobzhansky agrees, "Evolution as a whole doubtless had a general direction, from simple to complex, from dependence on to relative independence of the environment, to greater and greater autonomy of individuals, greater and greater development of sense organs and nervous systems conveying and processing information about the state of the organism's surroundings, and finally greater and greater consciousness." 26

What the random walk omits is the cybernetic, hereditary capacity of organisms to acquire, store, and transmit new information over historical time. Organisms start simple and some of them end up complex; there are trends over longer-range time scales because something is at work additionally to tracking drifting environments. The life process is drifting through an information search, locking onto discoveries. With such a conclusion the value question returns. If the system does produce both diversity and complexity, randomness is not the systemic story, however important it may be in the subplots.

\section{Blindness}

Williams, who thinks evolutionary nature selfish and pernicious, also thinks it blind. This follows from randomness on the cutting edge. Variations bubble up from the genetic level, as organisms compete for a place in drifting environments. Those few variations that are accidentally useful are selected for; the most, worthless, are discarded; some, to which even natural selection is blind, since they produce no differential survival rates, remain and result in genetic drift. Zig here, zag there, organisms stumble onto a life program. "The evolutionary process is immensely powerful and oppressive, ... it is abysmally stupid."27 "Clumsy" and "blundering" were Darwin's words. 
Now evolution has no sight, nor is it deliberate. Maybe it is not elegant. Evolution is a problem-solving process. Is this unguided, inept, disvaluable? The genetically originated novelties are formed in a shuffle that, while in some sense blind to the organismic needs, is far from chaotic. Only those variations are tested and selected that are more or less functional. The organism typically only probes the nearby space for possible directions of development. Mutators and animutators increase or trim the mutation rates as a function of population stresses. ${ }^{28}$ Repair mechanisms snip out certain genetic errors, and thus eliminate some variation. The genetic program has the capacity to "reject" some of the random recombinants on the basis of information already present in the genetic coding. Individual genetic sets are adept at pumping out their own disorder. But they do not pump out all novelty; that would cease evolutionary development and lead to extinction.

Contemporary geneticists are insisting that we misperceive this process if we think of it as blind. It is not deliberated in the conscious sense; but it is cognitive, somewhat in the way in which computers, likewise without felt experience, can run problem-solving programs. There is a vast array of sophisticated enzymes to cut, splice, digest, rearrange, mutate, reiterate, edit, correct, translocate, invert, and truncate particular gene sequences. There is much redundancy (multiple, variant copies of a gene in multi-gene families) that shields the species from accidental loss of a beneficial gene and provides flexibility on which these enzymes can work.

John H. Campbell concludes, "Cells are richly provided with special enzymes to tamper with DNA structure," enzymes that biologists are extracting for genetic engineering. But this "engineering" is already going on in spontaneous nature. "Gene-processing enzymes also engineer comparable changes in genes in vivo. ... We have discovered enzymes and enzyme pathways for almost every conceivable change in the structure of genes. The scope for self-engineering of multigene families seems to be limited only by the ingenuity of control systems for regulating these pathways." These pathways may have "governors" that are "extraordinarily sophisticated." "Self-governed genes are 'smart' machines in the current vernacular sense. Smart genes suggests smart cells and smart evolution, ... the promise of radically new genetic and evolutionary principles. ${ }^{29}$

So far from disparaging the blind groping of genes, computer scientists may deliberately seek to imitate a similar process on their unconscious computers. Some sophisticated programs use what are called "genetic algorithms." ${ }^{30}$ Such algorithms involve recombining partial solutions to a 
problem in order to generate improved solutions. The mode is biological with sexual mating and strings of genes on chromosomes that can be shuffled and selected. The underlying metaphor is natural selection. Scientists may want to program a computer to search for the optimal set of values to solve certain multivalued problems where the values interact with each other, such as solving sets of complex mathematical equations, or detecting patterns against a background of noise, or scheduling the most effective work and meeting times for many dozens of employees in a manufacturing plant.

The computer will generate at random some "bit strings," or "genotypes," analogous to information coded on chromosomes, which are possible values in solution. It will test members of the initial population for effectiveness as a solution, rank them for their "fitness," and select the fittest. The computer will then generate new solutions, stimulating variations on the highest ranking ones, inhibiting the lower ranking ones, evaluate the new possibilities for their fitness, and put them in competition with the previous, partially effective solutions. The computer also "mates" the various solutions, that is, cuts up and splices portions of bit strings that seem to code the most effective values, and then tests these "offspring" for their fitness. It works with coadjusted clusters that probably (but not inevitably) move together during crossover. It may vary the "population size" of the set of solution values that it mates. It will discard solutions with low fitness.

If two or more sets of solutions begin to appear that have little in common (widely separated local optima), the computer will preserve these multiple solution tracks, but try an occasional cross-mixing of segments from the different local optima, some of which will result in offspring that have enough fitness to remain in the working population. Such outbreeding prevents getting trapped in local optima that are not effective solutions globally. The computer will continue with lesser probability (which may be varied during the program) occasionally to explore unlikely solutions. Even in large and complicated search spaces, genetic algorithms tend to converge on solutions that are globally optimal or nearly so. Simple bit strings can encode complicated structures, and reiterated transformations of partial solutions have a striking power to improve them. Computer searches that would take a computer an estimated billion years, if done completely at random, can be accomplished in a few hours.

Genetic problem solving, then, does not seem so tinkering, jury-rigged, and blind. To the contrary, it is remarkably like what some of the smartest scientists are doing. Indeed, Herbert A. Simon finds the cutting edges of 
science itself like natural selection. "Various paths are tried; some are abandoned, others are pushed further. Before a solution is found, many paths of the maze may be explored. The more difficult and novel the problem, the greater is likely to be the amount of trial and error required to find a solution. At the same time, the trial and error is not completely random or blind; it is, in fact, rather highly selective. . . Human problem solving, from the most blundering to the most insightful, involves nothing more than varying mixtures of trial and error and slectivity." ${ }^{31}$

In nature, the challenge is to get as much versatility coupled with as much stability as possible, optimizing twin maxima. There is selective advantage in using past knowledge where possible; there is advantage in quickly breaking through to something new where required. The dominant/recessive phenomenon in genetics, with a large number of recessive alleles waiting in a population, is a way of storing variability that is not usually expressed in a stable environment, but which is nevertheless there when the environment shifts. ${ }^{32}$

So what is so disvaluable about genetic systems? It seems rather that there is valuable problem-solving taking place, and that this is taking place whether or not humans are present and doing any evaluating of it. Maybe there is more elegance than we first thought. Certainly there are remarkable success stories.

\section{Disaster}

Violent forces strike animals, plants, and people; disaster results. When human affairs are not touched, we may be unconcerned. Leopold mused, while sawing wood, "It was a bolt of lightning that put an end to wood-making by this particular oak. We were all awakened, one night in July, by the thunderous crash; we realized that the bolt must have hit near by, but, since it had not hit us, we all went back to sleep. Man brings all things to the test of himself, and this is notably true of lightning." ${ }^{33}$ If it didn't help or hurt me, it didn't help or hurt.

But we must try to bring things to some test outside ourselves. If the test is anthropocentric, all and only those bolts that hit humans or destroy what they value have disvalue; after that there is nothing more to be said. But this bolt did end the life of the good oak, and is that not a disvalue? Individually yes, but systemically? Lightning, like storms, fires, and floods, is statistically regular though individually erratic. At this moment 1,800 thunderstorms are raging around the globe, about 44,000 each day. Lightning is striking the Earth 100 times each second, over 8.6 million times each day. Earth is a sometimes turbulent planet. Is this turbulence, evidently bad 
when it catches individuals, a disvalue systemically? In 1988, lightning triggered Yellowstone fires that burned catastrophically. On July 21, 1987, 175-mile-an-hour tornado winds destroyed 15,000 acres in the Teton Wilderness of Wyoming. Catastrophic floods rip up riparian zones, as did the Big Thompson Flood in Colorado July 31, 1976. Such disruptions escalate the unrelated causal lines that tear things up.

Possibly these violent forces are bad, but there are good ones that overcome them. Possibly the catastrophic, negative forces are integrated with the uniformitarian, positive forces. Floods, windstorms, lightning storms, and such violences would be more or less like wildfire in ecosystems, a bad thing to individuals burned and in short range, but not really all that bad systemically in long range, given nature's restless creativity. Without thunderstorms, Earth would lose to the upper atmosphere, in less than an hour, the negative electrical charge that produces the atmospheric nitrogen upon which most plants depend. Without thunderstorms, playing electric charges over the thin hot soup, life could not have originated. Lightning has been essential to life. ${ }^{34}$

Often such violence comes with enough regularity that life can adapt - the oak with the stalwart trunk, ready for the winds; the lodgepole pines with their serotinous cones; the ecosystem rejuvenated by fires. Most bigscale processes are incremental, like mountain building over millennia; life can track such changing environments, often innovating and respeciating as it follows geomorphic history. Any event too infrequent to be naturally selected for is rare enough to be systemically atypical on most Earthen scales.

Rarely, this violence can come so spasmodically that life is unable to cycle onto it. We will then be hard pressed to say that these things can rejuvenate the ecological succession. Volcanic eruptions come every thousand years, and the ecosystem cannot adjust to their intermittent occurrence. They just disrupt and the ecosystem recovers as best it can. Even then life rejuvenates, value rises from the ashes of disvalue, and the system seems prolific once more. The incremental processes are punctuated by catastrophes, but nature is never too violent for life to continue - at least never yet in the several billion years of Earth history.

In March 1872 John Muir was in Yosemite Valley when it was struck by the Inyo earthquake: "I ran out of my cabin, near the Sentinel Rock, both glad and frightened, shouting, 'A noble earthquake!'... a terribly sublime and beautiful spectacle" ${ }^{35}$ "It is delightful to be trotted and dumpled on our Mother's mountain knee." ${ }^{36}$ Later, Muir concludes that the earthquake was "wild beauty-making business." "On the whole, by what at first sight 
seemed pure confusion and ruin, the landscapes were enriched; for gradually every talus, however big the boulders composing it, was covered with groves and gardens, and made a finely proportioned and ornamental base for the sheer cliffs." ${ }^{37}$ Muir once climbed a Douglas fir to ride out a storm, "to take the wind into my pulses and enjoy the excited forest from my superb outlook." 38 "Many of Nature's finest lessons are to be found in her storms." ${ }^{39}$

Is this Romanticism at its worst? Not really, for behind the poetry there is some botany, life persisting in the midst of its besetting storms. It is objective fact that the adverse, violent forces in dialectic with the prolific, enduring forces yield much of the romance of life. The violent forces of nature are as much to be celebrated for their creativity as for their destruction. The glaciers did carve the most spectacular scenery. Floods cut the valleys. Muir insisted that these are "Nature's modes of working toward beauty and joy." Volcanism is one of the mountain building forces; and, after the violence, life will return. "The cooled lava is forested now. The sun shines lovingly upon it, and all is joyous life." 40 "Storms of every sort, torrents, earthquakes, cataclysms, 'convulsions of nature,' etc., however mysterious and lawless at first sight they may seem, are only harmonious notes in the song of creation, varied expressions of God's love." ${ }^{41}$ Muir certainly has an intensive faith in natural systems, but such faith is not without some impressive evidence.

None of this means that, in our culturally rebuilt environments, we should not take shelter. After that, "ecstacy is a monster storm."

\section{Indifference}

In the California desert, April, May, and early June are usually good months; with rain and before the heat, the fauna and flora flourish. But sometimes the rains fail and the heat comes quickly. Mary Austin, recalls: "The quick increase of suns at the end of spring sometimes overtakes birds in their nesting and effects a reversal of the ordinary manner of incubation. It becomes necessary to keep eggs cool rather than warm. One hot, stifling spring in the Little Antelope I had occasion to pass and repass frequently the nest of a pair of meadowlarks, located unhappily in the shelter of a very slender weed. I never caught them sitting except near night, but at midday they stood, or drooped above it, half fainting with pitifully parted bills, between their treasure and the sun. Sometimes both of them together with wings spread and half lifted continued a spot of shade in temperature that constrained me at last in a fellow feeling to spare them a bit of canvas for permanent shelter." 43 
Barry Lopez recalls, "In the fall of 1973 an October rainstorm created a layer of ground ice that, later, muskoxen could not break through to feed. Nearly 75 percent of the muskox population in the Canadian Archipelago perished that winter." ${ }^{44}$ Like the meadowlarks, the muskoxen hit bad luck; the ice layer was of disvalue to the oxen, the blazing heat of disvalue to the larks. This is randomness now with brutal indifference to life. David Hume claimed that nature "has no more regard to good above ill than to heat above cold, or to drought above moisture, or to light above heavy." ${ }^{45}$ Or to life above nonlife, he would have added. That indifference can seem true in the short range, sometimes even in the long range. Nature doesn't care.

Is that all there is to be said? Though stressed on these occasions, those individuals are satisfactory fits in their ecosystems, and the nature that doesn't care is also the nature that provides life support. There the meadowlarks are, this pair in trouble, but the species nevertheless flourishes both East and West. So what are we to do? Curse this exception or rejoice in the usual? The muskoxen, decimated this one winter, continue on the tundra, living on for millennia, so well adapted to a polar existence that this is one of the few large animals to have survived the Ice Ages in North America. What are we to do: lament the October rainstorm or celebrate the tundra that has supported them for several million years? Or both?

As a species, organisms get selected for those functions and skills that enable them to do better in their niches, and what is so uncaring about that? Selection for adapted fit is a strange kind of indifference, an odd disvalue. The geomorphic, climatic, and even the biological processes can seem to have no axiological component at all. They just drift around in a mixture of cycles and random walk. Life arises in this geological kaleidoscope but no thanks to the elements. But then a different perspective on this earthen stew strikes us. This churn of materials, perpetually agitated and irradiated with energy, is not the problematic, indifferent resource but the prolific source. Against the indifference, we now must counter that the systemic results have been prolific, five million species flourishing in myriads of diverse ecosystems.

Maybe nature doesn't "care"; but nature does produce increased diversity and complexity. To say that there is nothing but systemic indifference ignores the principal result of natural history. Even if agnostic about the statistical worth of the whole, can anyone deny that repeated movements within it are prolific, values achieved here and there amidst the blooming buzzing confusion of nonvalues and disvalues - and all this objectively so whether or not humans take cognizance of these wild affairs? 
There is a kind of "promise" in nature, not only in the sense of potential that is promising but in the reliability in the earthen set-up that is right for life. Perhaps the planetary set-up is an accident, but the ongoing after the set-up seems to be loaded with fertility. In the short-range all lose, death is inevitable; but then again in the long-range life persists, phoenix-like, in the midst of its destruction. How much promise do we need? Isn't several billion years, with a turnover of several billion species, and a cumulation of several million species in almost every nook and cranny of Earth enough? Perhaps to say that nature "has regard" for life is the wrong way to phrase it; we do not want to ascribe purpose to nature. At the same time, nature is a fountain of life. That was the original etymology of "nature," from "natans," giving birth - and on Earth nature as birth is nearer the truth than nature as sheer indifference.

It seems a shame now for humans to break that "promise." We may not bring ourselves to say that nature is "keeping" any promise; that is not the right way to put it. But humans ought not to break what has been so promising in nature - not at least without an argument that the values they make in culture exceed the values they break in nature. It also seems uninformed to turn a philosophically taciturn gaze over all this promising, storied natural history and say, "Because I was not there, nor any other human, the question of value and disvalue cannot be asked. Argument over."

No argument has been won; none has been begun. Rather, we are not really going to be informed about what is going on in nature until we ask how value is achieved there, and we are not going to find an answer until we see that disvalues are regularly transmuted into values. The indifference to be lamented is not that in neg-valued or null-valued nature; the troublesome indifference lies in humans so careless about values outside the human sector.

\section{Waste}

Here an opposite thought strikes us. The nature indifferent to life is also ridiculously prolific; now the indifference is manifest not in niggard support but in unreasonable fecundity. The teeming kinds are cast forth to die. The nature complained against before because it was indifferent to life is complained against now because it produces it too lavishly. This profusion of creatures can seem inordinate and senseless, vigorous and horrible. Life is a good thing, but must the system waste it so?

The Salt Creek pupfish overwinters in permanent springs in Death Valley, several thousand individuals. With spring runoff, the population expands a hundred fold, spilling into downstream habitat; the waters abound 
with juvenile pupfish. Summer comes, the streams dry up, and the population is decimated again. ${ }^{46}$ The proliferation and die-off is extravagant, indifferent reproductive power. Heavy-seeded trees, such as oaks or hickories, may produce 200 million acorns or nuts to replace themselves once or twice, and light-seeded trees, like cotton woods produce billions. ${ }^{47} \mathrm{~A}$ pair of robins may produce thirty eggs to replace themselves once. Mother Nature seems spendthrift.

One response to prodigal life is to celebrate it. Thoreau exclaimed: "I love to see that Nature is so rife with life that myriads can be afforded to be sacrificed and suffered to prey on one another; that tender organizations can be so serenely squashed out of existence like pulp,- - tadpoles which herons gobble up, and tortoises run over in the road ... With the liability to accident, we must see how little account is to be made of it. ... Poison is not poisonous after all, nor are any wounds fatal." 48 This may be exuberance more than waste; the book of Genesis reports that God commanded the earth to bring forth "swarms" of creatures and found the prodigious result to be very good. ${ }^{49}$

Another question to ask is whether all those acorns, hickory nuts, seeds, and dead fishes really go to waste? They do, if nothing is of value unless and until humans value it. But "waste" is not the way that squirrels, blue jays, bears, deer look at acorns and nuts, nor mice the cottonwood seeds, nor the way the insect larvae, fungi, and decomposing bacteria approach the dead fish. One organism's waste is another organism's treasure. A muskox, laid waste by the ice sheet, becomes a carcass that benefits dozens of scavengers and predators. When something dies, something else lives. Nutritious pollens, fruits, and seeds may even evolve to be eaten, if this also facilitates dispersion by mobile animals and birds. Seed predators are often seed dispersers.

This alleged "waste" makes trophic pyramids possible. The lavish primary production of the grasses supports the ungulates; grass seeds support the granivorus rodents, whose fecundity supports the coyotes and owls. Insects pick up detritus and become food for birds. There is episodic surplus - an overkill of muskoxen, a horde of locusts. In odd situations, anomalies result. A mountain lioness got into a fold of sheep in Colorado laid down ninety-nine in one night's kill. But systemically on average, organisms must be efficient. There is capture of valuable nutrients and energy, which are recycled through the ecosystem in myriads of pathways. Animals partition out and use food resources in sequential stages. All living things are marginally pressed for survival; there is little waste. Wherever there is available free energy and biomass, a life form typically evolves to exploit those resources. Nature's exuberance is also nature's economy. 
Truth is, there is not much "waste" in natural systems, though there is exuberance and fecundity. What there is, if immediately a disvalue, is systemically transformed into something of value. And all this happens regardless of what humans think about it.

\section{Struggle}

The relentless struggle to survive can be supposed a disvalue. Adapted fit seems a good thing, but the shadow side is how each organism is doomed to eat or be eaten, to stake out what living it can in competition with others. Perhaps there is more efficiency than waste, more fecundity than indifference, but each organism is ringed about with competitors and limits, forced to do or die. Each is set as much against the world as within it. Physical nature, from which are wrested the materials of life, is brute fact and brutally there, caring naught and always threatening. Organic nature is savage; life preys on life.

Nature as a jungle does not mean that there are no valuers in the wild; it portrays too many claimants contesting scarce worth. Perhaps local achievements of value are wrested out of a disvaluable place? Or does the truth lie deeper? Perhaps the context of creativity logically and empirically requires this context of conflict and resolution. An environment entirely hostile would slay us; life could never have appeared within it. An environment entirely irenic would stagnate us; advanced life, including human life, could never have appeared there either. Oppositional nature is the first half of the truth; the second is that none of life's heroic quality is possible without this dialectical stress. Take away the friction, and would the structures stand? Would they move? Muscles, teeth, eyes, ears, noses, fins, legs, wings, scales, hair, hands, brains - all these and almost everything else comes out of the need to make a way through a world that mixes environmental resistance with environmental conductance. Half the beauty of life comes out of endurance through struggle.

In culture, humans relax these pressures of natural selection, though we cannot and do not eliminate the dimension of struggle. If human children catch pinkeye, physicians prescribe sodium sulfacetamide; but when the bighorns of Yellowstone caught pinkeye, they were left to the ravages of the disease. Being sick is a meaningless disvalue in a medically skilled culture; but the bighorn herd, surviving the epidemic, is stronger now. We count disease in domestic sheep a disvalue, because our resources are threatened; we call the veterinarian to cure it. But park officials let half the bighorn herd perish, letting nature take its course and valuing more the Chlamydia-resistant sheep that would survive, wilder and stronger than had they intervened to fix this disvalue in nature. 
Indeed, from this wilder perspective the domesticated is the degraded. Muir contrasts wild sheep, which he admires, "elegant and graceful as a deer, every movement manifesting admirable strength and character," with the domestic ones, which he despises, stupid "expressionless, like a dull bundle of something only half alive." ${ }^{50}$ If the standard of evaluation is our human subjective preferences, fashions in wool, the domesticated breeds can be better; but objectively, in natural systems, the wild sheep, honed to its strength, alertness, and endurance by the struggle for survival, is the more valuable. From this perspective, struggle is no disvalue (even though many sheep lose); it is the key to value achieved. Indeed, it is difficult to envision any of the properties admired (the horns, the eyesight, the agility, the musculature, the wool) except as created in this arduous environment. After a hunt on Mount Shasta, Muir examines closely the carcasses of a dead ram and ewe, and, repentant and chagrined by his kill, shouts, "Well done for wildness!" ${ }^{31}$

What is this struggle but a history of transvaluing disvalues into values? Disvalues and values are both objectively present in nature (regardless of human evaluators), nor is the struggle a zero sum game, nor null of value; rather, the struggle is prolific creativity.

\section{Suffering}

Over evolutionary history, with the diversity, complexity, and creativity we have celebrated, there emerges the capacity to suffer. Indeed the story could be titled, perversely, "The Evolution of Suffering." Each seeming advance - from plants to animals, from instinct to learning, from ganglia to brains, from sentience to self-awareness, from herbivores to carnivores - steps up the pain. In the planetary drama, struggle deepens through time into suffering. In chemistry, physics, astronomy, geomorphology, meteorology, nothing suffers; in botany life is stressed, but only in zoology does pain emerge. Is not this the evolution of increasing disvalue?

We are not much troubled by seeds that fail, but it is difficult to avoid pity for nestling birds fallen to the ground. In every season, most of the sentient young starve, are eaten, abused, abandoned. Wolves can get at the rump of a deer (avoiding the antlers); they may half-hamstring the deer and eat at it from behind. Sometimes a deer gets away with a hunk of its anus eaten out, to die slowly afterward. The Greek root for suffering is "pathos"; there are pathologies in nature, such as the diseases of parasitism, noted earlier. But pathology is only part of the disvalue; even in health there is suffering. Life is indisputably prolific; it is just as indisputably pathetic, almost as if its logos were pathos, as if the whole of sentient nature were pathological. "Horribly cruel!" exclaimed Darwin. 
We are trying not to be anthropocentric in our evaluation of nature; this means that animal suffering counts. This means also, however, that the human experience of suffering must not be projected indiscriminately onto the animal world. Suffering in some sense seems copresent with neural structures; there are endorphins in earthworms, which indicates both that they suffer and that they are provided with pain buffers. ${ }^{52}$ A safe generalization is that pain becomes less intense as we go down the phylogenetic spectrum and is often not as acute in the nonhuman world. It is a mistake to view the sufferings of animals, birds, replies too anthropopathically, too subjectively. Birds and reptiles typically have fewer nerve endings per surface area of skin, for instance; and the level of consciousness, self-awareness, or experience, or whatever is the proper name for their experiential state, is very different from, more subdued than, less intense and coherent than our own.

Nevertheless pain is objectively present, and is it sheer disvalue? A more adequate answer is that, just as struggle is the dark side of creativity, pain is logically and empirically the shadow side of pleasure; one cannot enjoy a world in which one cannot suffer, any more than one can succeed in a world in which one cannot fail. The logic here is not so much formal or universal as it is dialectical and narrative. In natural history-whatever might be true in other imaginable worlds - the pathway to psychosomatic consciousness, the only kind of experience we know, is through flesh that can feel its way through that world. There is some sentience without much capacity to be pained by it; we do not much suffer through our eyes or ears. But neither would we have those eyes and ears had they not evolved for the protection of the kinesthetic core of an experiential life that can suffer, whether by lack of food for which eyes may search or by predators whom ears may hear. We recouple here with the claims made about predation; levels of achievement and experience are generated in both predator and prey not otherwise possible.

The capacity to suffer is generally accompanied by possibilities of avoiding suffering, some freedom and self-assertion. The capacity to suffer, for instance, drives the capacity for learned behavior; it brings animal life to a central focus in sentient consciousness. This does not and cannot happen in plants. Thought appears in order to prevent pain and to affirm wellbeing, but the thought that cannot feel pain cannot figure out how to escape it. In humans, this evolution of thought seeking comfort drives the transition and exodus from nature to culture.

Pain is eminently useful in survival, and it will be naturally selected, on average, as functional pain. Natural selection requires pain as much as 
pleasure in the construction of concern and caring; pain is an alarm system in a world where there are helps and hurts through which a sentient organism must move. On the other hand, any population whose members are constantly in counterproductive pain will be selected against and go extinct or develop some capacities to minimize it. In this sense, natural selection, so far from needlessly increasing pain, rather trims it back in the system, so far as the system can remain vital — both conserving past vitalities and developing new ones. Pain is self-eliminating except insofar as it is instrumental of a subsequent, functional good. Intrinsic pain has no logical or empirical place in the system, neither does maladaptive pain. We cannot show this in the detail of every case; perhaps we need not expect it to be true in every case, and there are troublesome anomalies. Nevertheless, the system statistically must select for beneficial pain.

\section{Death}

Life is the first mystery that comes out of Earthen nature, and death a secondary one. But death comes as surely as life to all higher organisms. Even the lower forms that reproduce by cell fission or plant genets that produce ramets may and do die. So the great value, life, is countered by the great disvalue, death; and have we again a zero sum game? For each organism, the last word is destruction.

But we are trying to see nature systemically, where death is not the last word - at least it has never yet been across three and a half billion years. Death is the key to replacement with new life. If nothing much had ever died, nothing much could have ever lived. Just as the individual overtakes, assimilates to itself, and discards its resource materials, so the evolutionary wave is propagated onward, using and sacrificing particular individuals, which are employed in, but readily abandoned to, the larger currents of life. Thus the prolife evolution both overleaps death and seems impossible without it.

The vast number of creatures sprouted, hatched, or born, are, of necessity, more or less well-endowed genetically and emplaced in a more or less congenial environment, despite or including the fact that in their environment they are spurred to earn their way. Even though most will not live to maturity, their task is a reasonable natural ideal, a telos for which they are competently programmed. There are lethal mutants and monstrosities, but these bad ideas, as it were, are aborted immediately without further experiment. Organisms survive in about that proportion in which they are viable, so that life is sustained in any individual in relative proportion to its fitness for it. 
A community of life is systemically sustained, and this requires value capture as nutrients, energy, and skills are shuttled round the trophic pyramids. This anastomosing of life threads characterizes an ecosystem. The surplus of young is efficiently used as resource material in alternative life courses and is thus doubly beneficial, permitting both mutational, cybernetic advance and the interdependent synthesis of biotic materials with higher forms at the top of the pyramid. Overlaid on these interconversions natural selection edits life for evolutionary advance. There is the creation and conservation of life. Death in vivo is death ultimately; death in communitate is death penultimately but life regenerated ultimately.

Individual organisms must die; many of them (as though the genes had accepted this inevitability) are programmed to die. Annual plants die when they make fruit. Most anadromous fishes die after breeding, as do many mollusks, annelids, and insects. In mayflies and in some male salmon, and in some squids, the gut atrophies prior to the onset of breeding and the organism can no longer eat. It only remains to breed, and die. In this builtin senescence, the cycle of births and deaths is not a disvalue, or if it is, it is a disvalue that is overcome by valuable achievement that overleaps it. Reproduction necessitates death as much as does death necessitate reproduction.

Even if death is not preprogrammed, it is inevitable because of aging. Since life ages, a process that is not well understood, it can be perpetuated only by regeneration. This regeneration must be with variation, if there is to be creative advance or even tracking of changing environments. Death is part of the life cycle, not life part of the death cycle. But when naturehostile from the perspective of the slain-regenerates and regularly elevates life from the perspective of the community, is that a disvalue? When natural selection cuts away what does not fit and leaves what is better adapted, is that a disvalue?

Species do not have to die; their extinction is never programmed. Most, of course, do die. Ninety eight percent of all species that have ever existed did go extinct, so there are high probabilities, but there is no law of nature or inevitability about species extinction. But here a puzzling aspect of the matter strikes us. The death of the organism feeds into the nondeath of the species. Only by replacements can the species track the changing environment; only by replacements can they evolve into something else. Species sometimes do die, go extinct without issue, but they are often transformed into something else, new species; and, on average, there have been more arrivals than extinctions - the increase of both diversity and complexity over evolutionary history. We think of the extinction of species as tragic, if anthropogenic, because there is loss of birth as well as of death. But the loss of 
species in natural systems has meant more birth than death; perhaps there too it is tragic, but it is not unredeemed tragedy. Death is not the last word; death is transvalued into life.

\section{Systemic value}

Nature is random, contingent, blind, disastrous, wasteful, indifferent, selfish, cruel, clumsy, ugly, struggling, full of suffering, and, ultimately, death? This sees only the shadows, and there has to be light to cast shadows. Nature is orderly, prolific, efficient, selecting for adapted fit, exuberant, complex, diverse, renews life in the midst of death, struggling through to something higher. There are disvalues as surely as there are values, and the disvalues systemically drive the value achievements. We miss this panoramic creativity when we restrict value to human consciousness; we make value a prisoner of the particular sort of experiential biology and psychology that humans happen to have, or even of the particular sort of culture that humans happen to have chosen. There is every reason to value what we humans have achieved in our particular biology, sponsoring the emergence of culture as this biology does; there is no reason to think that value lies there and there alone.

All those who find nature to be disvaluable are making objective claims, and they are eventually wrong, not about the form of their claims, for they do try to make objective claims, nor altogether about the content of their claims, for they are locally right. Only they are systematically mistaken in evaluating what they describe, because their descriptions are myopic. Both objectively and globally there is both disvalue and value, and the transmuting of disvalue into value. Such nature is of systemic value, and a better description of what is objectively taking place makes this better evaluation possible, an evaluation that is as objective as is the description.

In this evaluation, we have not painted the world as better than it is in the interests of a philosophical metaphysics, nor worse either; rather we have tried to see into the depths of what is taking place in natural history. The view here is not panglossian; it is a sometimes tragic view of life, but one in which tragedy is the shadow of prolific creativity. That is the case, and the biological sciences - evolutionary history, ecology, molecular biology — can be brought to support this view, although neither tragedy nor creativity are part of their ordinary vocabulary. Since the world we have, in its general character, is the only world logically and empirically possible under the natural givens on Earth - so far as we can see at these native ranges that we inhabit - such a world ought also to be.

Annie Dillard explodes with horror over her Earth story. "I came from the world, I crawled out of a sea of amino acids, and now I must whirl 
around and shake my fist at that sea and cry Shame." ${ }^{53}$ If I were Aphrodite, rising from the sea, I think I would turn back to reflect on that event and rather raise both hands and cheer. And if I came to realize that this rising out of the misty seas involved a long struggle of life renewed in the midst of its perpetual perishing, I might fall to my knees in praise.

\section{Colorado State University}

Holmes Rolston, III

\section{NOTES}

1. Darwin, in a letter to Joseph Dalton Hooker, quoted in Gavin de Beer, Reflections of a Darwinian (London: Thomas Nelson and Sons, 1962), p. 43. In other moods, Darwin can find the process impressive and beautiful.

2. John Stuart Mill, "Nature" [1874], in Collected Works (Toronto: University of Toronto Press, 1963-77), vol. 10, pp. 373-402, citation on p. 398.

3. Thomas H. Huxley, "Evolution and Ethics" in T. H. Huxley and Julian Huxley, Evolution and Ethics (London: Pilot Press, 1947), p. 82.

4. George C. Williams, "Huxley's Evolution and Ethics in Sociobiological Perspective," Zygon 23 (1988), 383-407, citation on p. 383.

5. Shakespeare, Hamlet, Act II, Scene 2, Line 259.

6. Alfred, Lord Tennyson, In Memoriam [1850], Part LVI, Stanza 4.

7. Richard Dawkins, The Selfish Gene (New York: Oxford University Press, 1976), p. 2.

8. Steve F. Sapontzis, "Predation," Ethics and Animals 5, no. 2 (June 1984), 27-38, citation on p. 36 .

9. Alexander F. Skutch, "Life's Greatest Evil," The Scientific Monthly 66 (1948), 514-18, citation on p. 514.

10. Skutch, p. 516.

11. Stephen Jay Gould, Hen's Teeth and Horses' Toes (New York: W. W. Norton, 1983), p. 33.

12. Edward O. Wilson, Sociobiology: The New Synthesis (Cambridge: Harvard University Press, 1975), p. 371.

13. Arthur W. Jones, Introduction to Parasitology (Reading, MA: AddisonWesley, 1967), pp. 426-27.

14. A. C. Allison, "Co-evolution Between Hosts and Infectious Disease Agents and its Effects on Virulence." See also, with some dissent, J. C. Holmes, "Impact of Infectious Disease Agents on the Population Growth and Distribution of Animals"; and B. R. Levin, et al., "Evolution of Parasites and Hosts," all in R. M. Anderson and R. M. May, eds., Population Biology of Infectious Diseases (New York: Springer-Verlag, 1982). In an alternate theoretical outcome, the level of parasite virulence oscillates with host sensitivity. As we have repeatedly learned in ecosystems, relationships are complex, many other factors are involved (intermediate hosts, effects of and on predators, climate changes, geographical contingencies, genetic variability available), and generalizations are hazardous. 
15. David Richard Lincicome, "The Goodness of Parasitism: A New Hypothesis," in Thomas C. Cheng, ed., The Biology of Symbiosis (Baltimore, MD: University Park Press, 1971), pp. 139-227, citation on p. 139. See also Elmer R. Noble, Glenn A. Noble, Gerhard A. Schad, and Austin J. MacInnes, Parasitology: The Biology of Animal Parasites, 6th ed'n., (Philadelphia: Lea and Febiger, 1989); Thomas W. M. Cameron, Parasites and Parasitism (New York: John Wiley, 1958); Maurice Caullery, Parasitism and Symbiosis (London: Sidgwick and Jackson, 1952).

16. Williams, "Huxley's Evolution and Ethics," p. 385.

17. Ibid., p. 392.

18. Thomas Browne, Religio Medici [1643], Part I, Sec. 15, pp. 262-347 in Harvard Classics vol. 3 (New York: P. F. Collier and Son, 1909), citation on p. 278.

19. Francis Crick, What Mad Pursuit: A Personal View of Scientific Discovery (New York: Basic Books, 1988), p. 6, pp. 137-42.

20. Stephen Jay Gould, The Panda's Thumb (New York: W. W. Norton, 1980), p. 20.

21. Stephen Jay Gould, "Extemporaneous Comments on Evolutionary Hope and Reality," in Darwin's Legacy, Nobel Conference XVIII, ed. Charles L. Hamrum (San Francisco: Harper and Row, 1983), pp. 95-103, citation on pp. 101-02.

22. Stephen Jay Gould, "Chance Riches," Natural History 89, no. 11 (November 1980), 36-44.

23. James W. Valentine, "Patterns of Taxonomic and Ecological Structure of the Shelf Benthos During Phanerozoic Time," Palaeontology 12 (1969), 684-709, citation on p. 706.

24. James W. Valentine, Evolutionary Paleoecology of the Marine Biosphere (Englewood Cliffs, NJ: Prentice-Hall, 1973), p. 471.

25. Francisco J. Ayala, "The Concept of Biological Progress," in Francisco Jose Ayala and Theodosius Dobzhansky, eds., Studies in the Philosophy of Biology (New York: Macmillan, 1974), pp. 339-55, citation on p. 353.

26. Theodosius Dobzhansky, "Chance and Creativity in Evolution," in Ayala and Dobzhansky, eds., Studies in the Philosophy of Biology, pp. 307-37, citation on p. 311.

27. Williams, "Huxley's Evolution and Ethics," p. 400.

28. Eldon J. Gardner, Principles of Genetics, 5th ed'n., (New York: John Wiley, 1975), pp. 267-303.

29. John H. Campbell, "Evolving Concepts of Multigene Families," in Isozymes: Current Topics in Biological and Medical Research, Volume 10: Genetics and Evolution, 1983, pp. 401-17, citations on pp. 408-10, p. 414.

30. John H. Holland, Adaptation in Natural and Artificial Systems (Ann Arbor, MI: University of Michigan Press, 1975); John H. Holland, "Adaptive Algorithms for Discovering and Using General Patterns in Growing Knowledge Bases," International Journal of Policy Analysis and Information Systems 4 (1980), 245-68; Lawrence Davis, ed., Genetic Algorithms and Simulated Annealing (Los Altos, CA; Morgan Kaufman Publishers, 1987); David Goldberg, Genetic Algorithms in Search, Optimization, and Machine Learning (Reading, MA: Addison Wesley, 1989); Heinz Muhlenbein, M. Gorges-Schleuter, and O. Kramer, "Evolution Algorithms in Combinatorial Optimization," Parallel Computing 1 (1988), 65-85; D. Whitley, T. Starkweather and C. Bogart, "Genetic Algorithms and Neural Net works: Optimizing Connections and Connectivity," Parallel Computing 14 (1990), 347-61. 
31. Herbert A. Simon, The Sciences of the Artificial (Cambridge, MA: MIT Press, 1969), pp. 95, 97.

32. Francisco Ayala, "The Mechanisms of Evolution," Scientific American 239, no. 3 (September 1978), 56-69.

33. Aldo Leopold, Sand County Almanac (New York: Oxford University Press, 1968), p. 8.

34. John F. Deeks, "Some Electrifying Facts," Audubon vol. 83, no. 4 (July 1981), 56.

35. John Muir in The Wilderness World of John Muir, ed. Edwin Way Teale (Boston: Houghton Mifflin, 1954), pp. 166-67.

36. John Muir, To Yosemite and Beyond: Writings from the Years 1863-1875, ed. Robert Engberg and Donald Westing (Madison, WI: University of Wisconsin Press, 1980), p. 119.

37. Muir, Wilderness World, p. 169.

38. John Muir, The Mountains of California (New York: Viking Penguin, 1985), p. 176

39. John Muir, Stickeen [1897] (Berkeley, CA: Heydey Books, 1990), p. 21.

40. John Muir, John of the Mountains: The Unpublished Journals of John Muir, ed. Linnie Marsh Wolfe (Boston: Houghton Mifflin, 1938), p. 213.

41. Muir, Wilderness World, p. 169.

42. John F. Deeks, "Ecstacy is a Monster Storm," Audubon vol. 83, no. 4 (July 1981), 50-55.

43. Mary Austin, The Land of Little Rain (Boston, MA: Houghton Mifflin, 1903), pp. 14-15.

44. Barry Lopez, Arctic Dreams (New York: Charles Scribner's Sons, 1986), p. 32.

45. David Hume, Dialogues Concerning Natural Religion, ed. Henry D. Aiken (New York: Hafner, 1948, 1972), p. 79.

46. David L. Soltz and Robert J. Naiman, The Natural History of Native Fishes in the Death Valley System (Los Angeles: Natural History Museum of Los Angeles County, Science Series 30, 1978), pp. 39-42.

47. Herman H. Shugart, Jr., and Darrell C. West, "Long-Term Dynamics of Forest Ecosystems, American Scientist 69 (1981), 647-52.

48. Henry David Thoreau, Walden (Boston, MA: Houghton Mifflin, 1938), p. $350-51$.

49. Genesis 1: 20-23.

50. Muir, Mountains of California, pp. 210-11.

51. John Muir, "Wild Wool" (1875) in Wilderness Essays (Salt Lake City, UT: Peregrine Smith, 1980), pp. 227-42, citation on p. 229.

52. J. Alumets, R. Hakanson, F. Sundler, and J. Thorell, "Neuronal Localisation of Immunoreactive Enkephalin and Beta-Endorphin in the Earthworm," Nature 279 (1979), 805-06.

53. Annie Dillard, Pilgrim at Tinker Creek (New York: Bantam Books, 1974), p. 180. Dillard, a poet, knows other moods; sometimes her world is a burning bush, "the tree with the lights in it" (p. 35). 